\title{
Cisplatin effect on head and neck squamous cell carcinoma cells is modulated by ERK1/2 protein kinases
}

\author{
MARINELA BOSTAN ${ }^{1,2}$, GEORGIANA GABRIELA PETRICĂ-MATEI ${ }^{3}$, GABRIELA ION $^{1}$, NICOLETA RADU ${ }^{4,5}$, \\ MIRELA MIHĂILĂ ${ }^{1}$, RĂZVAN HAINĂROŞIE ${ }^{6}$, LORELEI IRINA BRAŞOVEANU ${ }^{1}$, VIVIANA ROMAN ${ }^{1}$, \\ CAROLINA CONSTANTIN ${ }^{2}$ and MONICA TEODORA NEAGU ${ }^{2}$

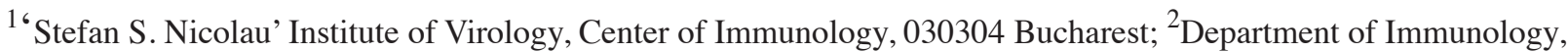 \\ 'Victor Babeș' National Institute of Pathology, 050096 Bucharest; ${ }^{3}$ Department of Cytogenetics, \\ Personal Genetics - Medical Genetics Center, 010987 Bucharest; ${ }^{4}$ Department of Biotechnology, \\ University of Agronomic Sciences and Veterinary Medicine of Bucharest, 011464 Bucharest; \\ ${ }^{5}$ Biotechnology Department and National Institute for Chemistry and Petrochemistry R\&D of Bucharest, 060021 Bucharest; \\ ${ }^{6 ‘}$ Prof. Dr. Dorin Hociotă' Institute of Phonoaudiology and Functional ENT Surgery, 061344 Bucharest, Romania
}

Received September 2, 2019; Accepted October 3, 2019

DOI: $10.3892 / \mathrm{etm} .2019 .8139$

\begin{abstract}
The extracellular signal-regulated kinases (ERKs) are key transducers of the extracellular signals into intracellular responses and represent major molecular players in tumorigenesis. The aim of this study was to determine how curcumin (CRM) used as an adjuvant supports the apoptotic process induced by a single chemical agent treatment (cisplatin-CisPT) on two head and neck squamous cell carcinoma cell lines (FaDu and PE/CA-PJ49) and the involvement of ERK1/2 and/or p53 activation in this process. Data have shown that the CisPt effect is potentiated by CRM. CRM induced an increase of p53 protein phosphorylation in both cell lines.
\end{abstract}

Correspondence to: Dr Viviana Roman, 'Stefan S. Nicolau' Institute of Virology, Center of Immunology, 285 Mihai Bravu Ave, S3, 030304 Bucharest, Romania

E-mail: rviviana30@yahoo.com

Abbreviations: CisPt, cisplatin; CRM, curcumin; ERK1/2, extracellular signal-regulated kinase; FISH, fluorescence in situ hibridization; PD98059, (2'-amino-3'-methoxyflavone); MTT, (3-(4,5-dimethylthiazol-2-yl)-2,5-diphenyltetrazolium bromide); DMSO, dimethyl sulfoxide; EDTA, etylenediaminetetraacetic acid; PBS, phosphate-buffered saline; FaDu, human pharynx squamous cell carcinoma; PE/CA-PJ49, human tongue squamous cell carcinoma; DMEM, Dulbecco's modified Eagle's medium; FBS, fetal bovine serum; TP53, the tumor suppressor gene TP53; DAPI II, 4',6-Diamidino-2-phenylindole; SSC buffer, the saline-sodium citrate buffer; NP-40, detergent solution; FITC, fluorescein isothiocyanate; PI, propidium iodide; PMSF, phenylmethylsulfonyl fluoride; ELISA, enzyme-linked immunosorbent assay.

Key words: head and neck tumor cells, cisplatin, curcumin, p53, apoptosis, ERK1/2
CisPt decreased p53 protein phosphorylation in FaDu cells, but increased it in PE/CA-PJ49 cells. Data showed that the constitutive expression of activated ERK1/2 protein-kinase was different in the two analyzed tumor cell lines. ERK1/2 activation status was essential for both cell processes, proliferation and apoptosis induced by CisPt and/or CRM treatment on squamous cell carcinoma cells. Our data suggest that p53 phosphorylation in the apoptotic process induced by CRM treatment might require the involvement of ERK1/2. In this regard the CisPt treatment suggested that $\mathrm{p} 53$ phosphorylation is ERK $1 / 2$ independent in FaDu cells having a p53 gene deletion and ERK1/2 dependent in PE/CA-PJ49 cells having a p53 gene amplification. Moreover, in both tumor cell lines our results support the involvement of p53 phosphorylation-ERK1/2 activation-dependent in the apoptosis induced by combined treatments (CisPt and CRM). The use of CRM as adjuvant could increase the efficiency of chemotherapy by modulating cellular activation processes of ERK1/2 signaling pathways. In conclusion, the particular mode of intervention by which ERK1/2 might influence cell proliferation and/or apoptosis processes depends on the type of therapeutic agent, the cells' particularities, and the activation status of the ERK1/2.

\section{Introduction}

Oral cavity cancer has shown an increased incidence in recent years in Romania (1) and also worldwide (2). The most commune type of oral cavity cancer is squamous cell carcinoma (commonly referred as 'Head and Neck Squamous Cell Carcinoma', HNSCC). The disease affects several anatomic structures: Oral cavity, oropharynx, nasopharynx, hypopharynx and larynx (3-5). Most of HNSCC patients are, unfortunately, diagnosed when the disease has already progressed to an advanced stage. In this instance the therapeutic approach is complex and involves the combination of chemo and radiotherapy either before or after the surgical procedure based on the protocol established for each patient (6-8). Thus, 
the protocols are somewhat personalized, hower, the development of resistance to conventional treatments and an increased recurrence rate of primary tumors lead to a 5-year decline of the survival rate of patients with HNSCC (9-12). Therefore, additional clinical approaches of this complex disease are needed. The new therapeutic strategies have to tackle at least two points, besides increasing the survival rate, it should reduce the adverse effects of chemotherapy. The use of natural compounds as adjuvants can be beneficial by increasing the efficacy of conventional treatments and very importantly to limit the adverse reactions. The disruption of normal cellular mechanisms such as proliferation or apoptosis, is accountable for the development of tumoral processes in different types of cancer, including HNSCC. Apoptosis, known as 'programmed cell death', is a mechanism that provides crucial control over the cell homeostasis. Apoptosis enables the removal of cells having DNA mutations, aberrant cellular cycle and that are prone to malignant transformation $(13,14)$. Defects observed in the apoptotic pathway associated to cancer have an important role in conventional oncotherapies (radio- and chemotherapy) since apoptosis induction needs high dosages of therapeutic agents. Cisplatin (CisPt), one of the most used chemotherapeutic agent in HNSCC treatment, has the capacity to interact with DNA, RNA and different proteins, and by activation of specific mechanisms, some of them still incompletely known, can induce apoptosis (15-17).

The elucidation of the mechanisms pertaining to the apoptosis process is a key step. The restoration of the cellular mechanisms responsible for tumor cell apoptosis are of upmost importance in malignant transformation, tumor evasion and anticancer therapy (18-20). Factors that determine a damaged cell to go either through apoptosis or to repair the damage and continue the cell cycle, are still to be discovered. It is well known that one important apoptosis regulator is the tumor suppressor gene TP53 (TP53). TP53 tumor suppressor has mutations in $40-60 \%$ of the HNSCC cases (21). This is an untimely event, identified in precancerous lesions and associated with a poor prognosis. Some studies showed that the rehabilitation of the TP53 function in an early stage of the disease had no effect, but can lead to the regression of the tumor in advanced stages $(22,23)$. This suggests that TP53 tumor suppressor is not activated in the early phases of the disease, but can be activated in later phases of tumorigenesis $(24,25)$. Another important player in the regulation of cell tumorigenesis-related functions (proliferation, transformation, differentiation, apoptosis, angiogenesis) is activation of mitogen-activated protein kinases (MAPKs) pathways such as ERKs (26-30). There are studies showing that the activation of the MAPK pathway is correlated with the cancer prognosis influencing the therapeutic outcome in many types of cancer (31-33). Correlated once with the intimate deciphering of molecular pathways that regulate oncogenesis, new modern and specific therapies able to improve the current therapeutic methods will be developed. One of the approaches is to maximize the effectiveness of initial therapy by the use of a chemotherapeutic drug together with a supporting agent (34). Some studies have been focused on the discovery of new therapeutic agents obtained from natural compounds proving anticancer and anti-proliferation effects $(35,36)$. One of these compounds is curcumin (CRM). $\mathrm{CRM}$ is the principal compound of turmeric extracted from the plant Curcuma longa and has many diverse properties anti-inflammatory, anti-bacterial, anti-fungal, anti-viral and anti-carcinogenic (37). The mechanisms through which CRM exerts its antitumoral effects are complex and diverse; they appear to act in the processes of growth and apoptosis and also in different stages of carcinogenesis $(38,39)$.

Acknowledging all the mentioned issues in the this type of carcinoma the focus of this study is to investigate how a natural adjuvant (CRM) supports the apoptotic process induced by a mono chemical standard agent ( $\mathrm{CisPt}$ ) in an in vitro experimental model using HNSCC standard cell lines. Moreover, in our study we investigated the ERK1/2 and/or p53 involvement in treatment response. The use of adjuvant might have a beneficial effect decreasing the CisPt doses, therefore reducing the adverse reactions induced by a chemotherapeutic agent.

\section{Materials and methods}

Cell lines culture. The squamous carcinoma cell line PE/CA-PJ49 was from European Collection of Authenticated Cell Cultures (ECACC cat. no. 0060606). The cell line was obtained from a 57-year old male patient with tongue carcinoma. The FaDu cell line was obtained from the American Type Culture Collection (ATCC-HTB-43 cat.). The cell line was derived from a 56-year-old male patient with pharyngeal squamous cell carcinoma. Both lines are showing adherent epithelial type morphology. The cell lines were grown and maintained in Dulbecco's modified Eagle's medium (DMEM) supplemented with $10 \%$ fetal bovine serum (FBS), 2 mM glutamine, $1 \%$ penicillin, and $1 \%$ streptomycin at $37^{\circ} \mathrm{C}$ in $5 \% \mathrm{CO}_{2}$. The sub-confluent cultures (70-80\%) were split 1:4-1:8 (i.e. seeding at $1-3 \times 10,000$ cells $\left./ \mathrm{cm}^{2}\right)$ using trypsin-EDTA $(0.25 \%$ trypsin, $0.03 \%$ EDTA).

The study protocol was approved by the Ethics Committee of 'Stefan S. Nicolau' Virology Institute.

Drugs and treatments. CisPt and CRM (97\% purity), were obtained from Sigma-Aldrich. They were initially dissolved in dimethyl sulfoxide (DMSO; Sigma-Aldrich) at a concentration of $5 \mathrm{mM}$. Further, milli-Q water was used to generate $1 \mathrm{mM}$ stock solutions. The stock solutions were filtered using a cellulose acetate hydrophilic filter $(0.20 \mu \mathrm{m})$ (Sigma-Aldrich). Dilutions used in the experimental model were done in DMEM to generate the following concentration ranges: $2-160 \mu \mathrm{M}$ for CisPt and 5-100 $\mu \mathrm{M}$ for CRM. Tumor cells were incubated for 6, 24 or $48 \mathrm{~h}$ either in the presence of the drugs ( $\mathrm{CisPt}$ and/or CRM) or vehicle control (DMSO $\leq 0.1 \%$ ). For inhibition studies of ERK1/2 function, the cells were pre-incubated for $2 \mathrm{~h}$ with $25 \mu \mathrm{M}$ PD98059 as previously reported (40). The treated tumor cells were used to determine cell proliferation, FISH, apoptosis and conserved as cell pellets at $-80^{\circ} \mathrm{C}$ in order to obtain cell lysates used in ELISA assays. Non-treated cells were used as controls throughout the experiments.

Cell viability assay. Tumor cells $\left(1-2 \times 10^{3}\right.$ cell/well) were seeded in 96-microwell plates, incubated at $37^{\circ} \mathrm{C}$ for $24 \mathrm{~h}$ to accomplish full adherence and then treated with different concentrations of CisPt (2-160 $\mu \mathrm{M})$ or CRM (5-100 $\mu \mathrm{M})$. The cell viability was assessed by the ability of metabolically 
active cells to reduce the 3-(4,5-dimethylthiazol-2-yl)-2,5-diphenyltetrazolium bromide (MTT) (Sigma-Aldrich) to colored formazan compounds. The absorbance was measured with an enzyme-linked immunosorbent assay reader (Dynex plate reader; wavelength $450 \mathrm{~nm}$ ) (41). The data are presented as the mean values from at least three different experiments. Untreated cells served as control having $100 \%$ viability. Viability $\%=(\mathrm{T}-\mathrm{B}) /(\mathrm{U}-\mathrm{B}) \times 100$, (where $\mathrm{T}$, absorbance of treated cells; U, absorbance of untreated cells, iar B, absorbance of blank).

Cell proliferation assay. CellTiter $96{ }^{\circledR}$ AQueous One Solution Cell Proliferation Assay (Promega) was used. The test is based on the reduction of yellow MTS tetrazolium salt by the viable cells and generation of colored formazan soluble in the culture medium. The product was spectrophotometrically quantified by measuring the absorbance at $\lambda=490 \mathrm{~nm}$ (42) using a Dynex plate reader (DYNEX Technologies-MRS). Results were expressed as mean values of three determinations \pm standard deviation (SD). Untreated cells served as control and considered to have proliferation index (PI) equal 1 . PI = absorbance of treated cells/absorbance of untreated cells.

Fluorescence in situ hybridization. FISH technique was performed after optimization of the protocol using commercially available probe from Abbott/Vysis (Vysis) $(43,44)$. According with the manufacturer's protocol Locus specific identifier LSA TP53/CEP17 FISH Probe Kit detects the LSI TP53 probe Spectrum Orange target located on chromosome 17p13.1 and CEP17 (17p11.1-q11.1 Alpha Satellite) probe Spectrum Green Dual Colour target located on the centromere of chromosome 17.

Cells and slide preparation: The slides were cleaned in an ice-cold mixture of $40 \%$ methanol and $60 \%$ distilled water, then air dryed and stored at $4^{\circ} \mathrm{C}$. Cells were pelleted and suspended in $0.075 \mathrm{M} \mathrm{KCl}$ hypotonic solution for $20 \mathrm{~min}$ at $37^{\circ} \mathrm{C}$. Tumor cells were pelleted by centrifugation at $300 \mathrm{x} \mathrm{g}$ for $5 \mathrm{~min}$ at $4^{\circ} \mathrm{C}$ and resuspended in $0.5 \mathrm{ml}$ fixative (3:1 methyl alcohol and glacial acetic acid). Afterwards the cells were diluted at the appropriate density and distributed on several locations on the slide. The air dried slides were incubated at $-20^{\circ} \mathrm{C}$ for $30 \mathrm{~min}$.

FISH probe preparation and hybridization from cell culture: The slides were denatured for $5 \mathrm{~min}$ in $70 \%$ formamide/2X SSC at $73^{\circ} \mathrm{C}$. Then the slides were dehydrated by immersion in 70,80 and $100 \%$ cold ethanol solution, 5 min for each step. The slides were air-dried and $10 \mu 1$ of the probe LSI TP53/CEP17 was added in the selected hybridization area. The smears were covered with a 22x22 mm coverslip, sealed and incubated overnight in a humid chamber at $37^{\circ} \mathrm{C}$. Two washes were performed post hybridization, using washing solutions: $0.4 \mathrm{X} \mathrm{SSC} / 0.3 \% \mathrm{NP}-40$ at $73^{\circ} \mathrm{C}$ for $2 \mathrm{~min}$, and $2 \mathrm{X} \mathrm{SSC} / 0.1 \% \mathrm{NP}-40$ for $2 \mathrm{~min}$. The slides were air-dried and 4',6-diamidino-2-phenylindole (DAPI II) was added for counterstaining. The slides were analyzed using a Zeiss Axio Imager M1 epifluorescence microscope (Zeiss) equipped with filters for DAPI, SpectrumOrange and SpectrumGreen and a triple filter (simultaneous DAPI/Orange/Green). Images were acquired at a magnification of $\mathrm{x} 1,000$ and captured using MetaSystems digital camera. Images were analyzed using Isis version 5.2, MetaSystems software for quantitative analysis of samples generated by FISH technique (Altlussheim). For each sample hybridized signals were counted in 100 nuclei.

ELISA assay. ELISA assays were used to measure both total and phosphorylated p53 and ERK1/2proteins in cell lysates. Briefly, untreated, CisPt and/or CRM treated tumor cells were lysed in PBS (pH 7.2-7.4) containing 1 mM EDTA, $0.5 \%$ Triton $\mathrm{X}-100,5 \mathrm{mM} \mathrm{NaF}, 6 \mathrm{M}$ urea, $10 \mu \mathrm{g} / \mathrm{ml}$ leupeptin, $10 \mu \mathrm{g} / \mathrm{ml}$ pepstatin, $100 \mu \mathrm{M}$ PMSF, $3 \mu \mathrm{g} / \mathrm{ml}$ aprotinin, $2.5 \mathrm{mM}$ sodium pyrophosphate, $1 \mathrm{mM}$ sodium orthovanadate. The lysate was kept $30 \mathrm{~min}$ on ice with stirring every $5 \mathrm{~min}$. The lysate was centrifuged at 2,000 $\mathrm{x} \mathrm{g}$ for $5 \mathrm{~min}$ at room temperature. Furthermore, the obtained supernatant was centrifuged at $14,000 \mathrm{x}$ g for $15 \mathrm{~min}$ at $4^{\circ} \mathrm{C}$. Protein concentration of the lysates was measured using Bradford assay. DuoSet_IC Human Total p53 ELISA [cat. no. DYC1043]; DuoSet_IC Human Phospho-p53 (S15) ELISA [cat. no. DYC1839]; DuoSet_IC Human/Mouse/Rat Total ERK1/2 [cat. no. DYC1940] DuoSet_IC Human/Mouse/Rat PhosphoERK1/2 ELISA [cat. no. DYC1018B] were purchased from R\&D Systems Inc. The protein of interest was measured using a standard Streptavidin-HRP system (45). All experiments were performed in triplicates and sample O.D. was measured at $\lambda=450 \mathrm{~nm}$ using Dynex plate reader.

Analysis of apoptosis. The apoptosis assay was carried out with the Annexin V-FITC kit using the manufacturer's protocol (BD Pharmingen) (46). Treated and untreated $1 \times 10^{6}$ cells $/ \mathrm{ml}$ were resuspended in cold binding buffer and staining simultaneously with $5 \mu \mathrm{l}$ FITC-Annexin V (green fluorescence) and $5 \mu \mathrm{l}$ propidium iodide (PI) in the dark at room temperature for $15 \mathrm{~min}$. Then $400 \mu \mathrm{l}$ of Annexin $\mathrm{V}$ binding buffer was added and 10,000 cells/sample were acquired using BD Canto II flow cytometer. The analysis was performed using DIVA 6.2 software in order to discriminate viable cells (FITC-PI') from necrotic cells $\left(\mathrm{FITC}^{+} \mathrm{PI}^{+}\right)$and early apoptosis $\left(\mathrm{FITC}^{+} \mathrm{PI}^{-}\right)$from late apoptosis.

Statistical analysis. Data were analyzed using Student's t-test (paired type and one tailed distibution). One-way analysis of variation with $\mathrm{P}$-value of $<0.05$ was considered statistically significant.

\section{Results}

Culture parameters of the standardized cell lines used in in vitro experiments. In the present study two human HNSCC cell lines were used, FaDu derived from pharyngeal squamous carcinoma and PE/CA-PJ49 obtained from a tongue squamous carcinoma, both cell lines presenting adherent and epithelial-type morphology. To achieve the successive passages of cells kept in culture, the density of cells in the culture plates were carefully supervised in order to avoid over-population and any sign of aging. At the end of each experiment, samples from used cells were frozen to create a batch of cells that can be used anytime to repeat or continue the experiments. Some studies have shown that the number of cells that present with polysomy at the level of the 17 th chromosome is raised in oral cavity squamous carcinomas and this may be correlated with the process of carcinogenesis (47). The exact role of genetic 
A

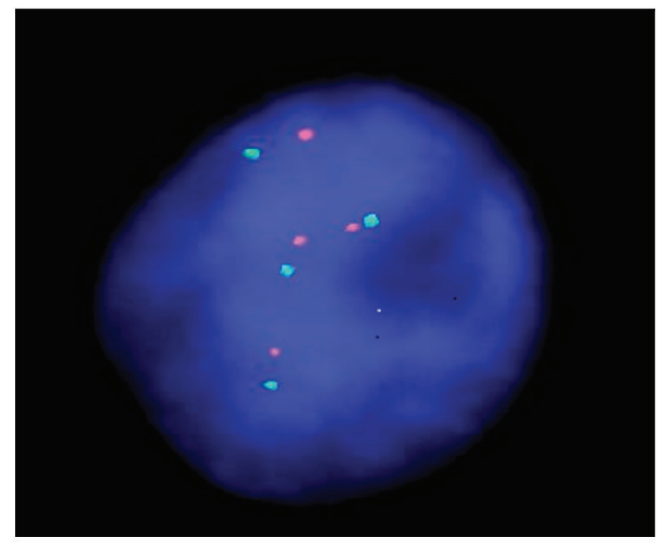

B

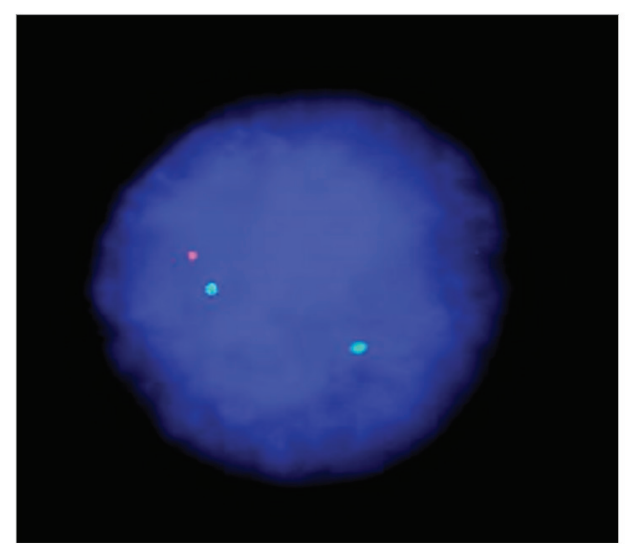

Figure 1. Fluorescent in situ hybridization analysis of TP53 gene performed on PE-CA/PJ49 (A) and FaDu (B) tumor cells. Two targets, LSI TP53 probe Spectrum Orange target located at chromosome 17p13.1 and CEP17 (17p11.1-q11.1 Alpha Satellite) probe Spectrum Green Dual Colour target located at the centromere of chromosome 17, were detected by locus specific identifier LSA TP53/CEP17 FISH Probe. The data were aquired at a magnification of x1,000. The hybridized signals were counted in 100 nuclei for each sample. (A) PE-CA/PJ49 cells showed 4 red signals for both targets TP53 (amplified gene) and CEP17 (tetrasomy). (B) FaDu cells showed 1 red signal for TP53 (gene deletion) and 2 green signals for CEP17 (normal chromosome number).

modifications of TP53 in different stages of the tumorigenesis process is not completely established, but it is known that the gene has the ability to induce the restoration of damaged DNA by activating certain proteins and by stopping the cellular cycle and induction of apoptosis. Thereby, it has been tried to identify some possible numeric aberrations of chromosome 17, such as deletion or amplification of TP53 gene in the FaDu and PE/CA-PJ49 cells. This genetic endeavor was done in order to discover possible explications between these abnormalities and the cellular response to therapy. Using the FISH technique, the intention was to obtain information on the TP53 gene status in the FaDu and PE/CA-PJ49 tumor cells before starting the experiments. The PE/CA-PJ49 tumor line showed an amplification of the TP53 gene since all analyzed cells had 4 signals for both TP53 (17p13) (red dots on Fig. 1A) and 17(D17Z1) centromere probe (green dots on Fig. 1A). FaDu did not show the amplification of TP53 gene on chromosome 17. In contrast to this, the cells had only one signal for TP53 (17p13) (red dot on Fig. 1B) suggesting a deletion of the TP53 gene, without modification at the level of chromosome 17 which presented only two signals for the 17(D17Z1) centromere (green dots Fig. 1B).

Effects of cisplatin and/or curcumin treatment on the cellular viability of HNSCC. Cisplatin is one of the most utilized cytostatic drugs in the treatment of HNSCC. Unfortunately many patients develop relapses or cisplatin resistance. A natural compound such as curcumin might improve and maintain the antitumoral effect of cisplatin. In order to determine the optimal concentration of the drug needed to inhibit half of the maximum biological response $\left(\mathrm{IC}_{50}\right)$ both tumor cell lines were treated with the following concentrations 0,1 , 5, 10, 20, 40, 80, $160 \mu \mathrm{M}$ CisPt or $0,5,10,15,20,25,50$, $100 \mu \mathrm{M}$ CRM. To determine the optimal treatment time, cells were treated for different time periods $(6,24$ or $48 \mathrm{~h})$. The inhibitory effect of CisPt or CRM on the cellular viability was dose- and time-dependent (Fig. 2). The results showed that $24 \mathrm{~h}$ CisPt treatment had an $\mathrm{IC}_{50}=11.25 \mu \mathrm{M}$ for $\mathrm{FaDu}$ cells and $\mathrm{IC}_{50}=10.55 \mu \mathrm{M}$ for PE/CA-PJ49 cells. CRM treatment for $24 \mathrm{~h}$ reduced the cellular viability with an $\mathrm{IC}_{50}=13.72 \mu \mathrm{M}$ for $\mathrm{FaDu}$ cells and $\mathrm{IC}_{50}=15.20 \mu \mathrm{M}$ for PE/CA-PJ49 tumor cells. Based on the obtained results the optimal time of treatment was $24 \mathrm{~h}$ and the optimal concentration was $10 \mu \mathrm{M}$ for CisPt and $15 \mu \mathrm{M}$ for CRM (Fig. 2). We tested concentrations less than $2 \mu \mathrm{M}$ (data not shown) and they did not have any effect on the treated FaDu or PE/CA-PJ49 cells.

The effect of the CisPt and/or CRM treatment on the protein-kinase ERK1/2 expression. MAPKs transmit and amplify the signals involved in proliferation, as well as in cellular death. Using ELISA assay, we evaluated the expression and activation of protein-kinase ERK1/2 induced by CisPt and/or CRM treatment of FaDu and PE-CA/PJ49 tumor cells. The data show that in the tumor cells treated with CisPt and/or CRM for different time-points, the ERK1/2 protein-kinase is highly expressed after $24 \mathrm{~h}$ treatment. The untreated PE-CA/PJ49 cells (control) have a statistically significant higher expression of total ERK1/2 (4.3 ng/mg protein) compared to untreated FaDu cells (1.87 ng/mg protein) (Fig. 3). The CisPt and/or CRM treatment applied individually or in combination did not significantly modify the expression of total ERK1/2 form in the two analyzed tumor cell lines (Fig. 3A). In order to analyze the effect of CisPt and/or CRM treatment on the activation of ERK1/2, the level of ERK1/2 phosphorylation (\% phospho-ERK1/ERK2) was quantified. The results show that $\mathrm{FaDu}$ cells responded differently to treatment compared to PE-CA/PJ49 cells.

In untreated FaDu cells $37 \%$ of ERK1/2 protein was phosphorylated and under the $10 \mu \mathrm{M}$ CisPt and/or $15 \mu \mathrm{M}$ CRM treatment the phosphorylation was not significantly modified compared to the untreated cells (Fig. 3A and B). In untreated PE-CA/PJ49 cells $80 \%$ of ERK1/2 was phosphorylated (Fig. 3B), $10 \mu \mathrm{M}$ CisPt alone slightly reduced the level of phosphorylation of ERK1/2 to $73 \%$ (a; $\mathrm{P}=0.03$ ), and $15 \mu \mathrm{M}$ CRM per se induced a significant inhibition of ERK1/2 phosphorylation (41\%, b; P=0.003) (Fig. 3B).

The combined treatment, CisPt and CRM, led to a significant reduction $(42 \%)$ of the ERK1/2 phosphorylation 
FaDu
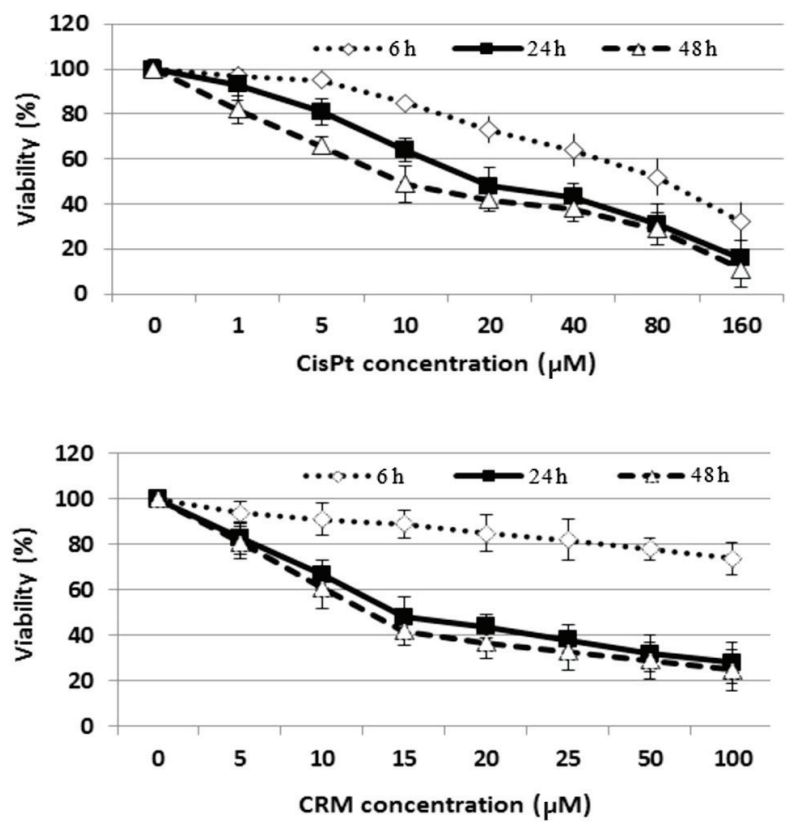

PE/CA-PJ49
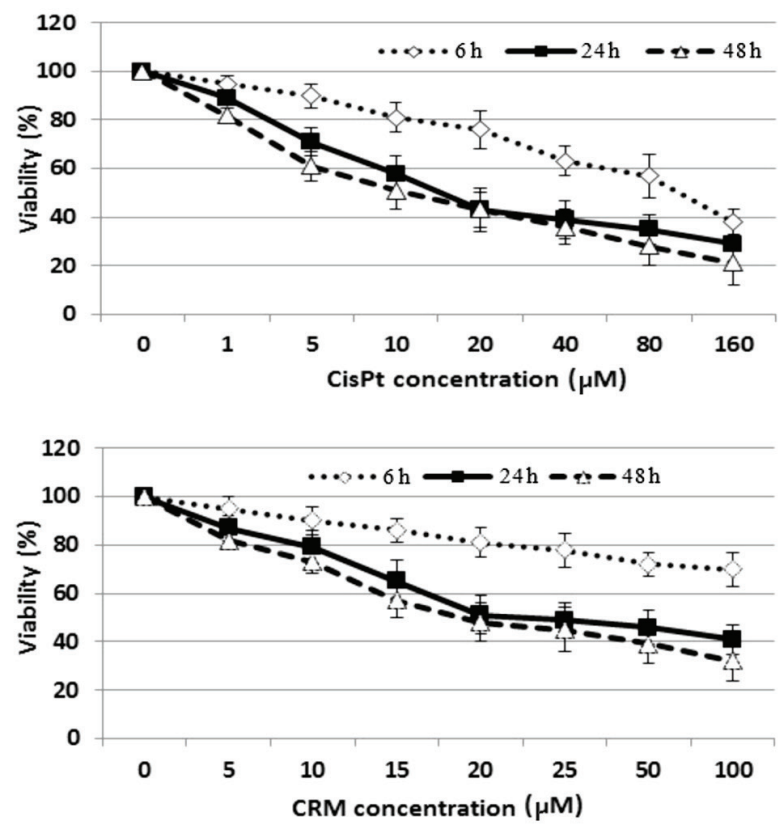

Figure 2. Effect of CisPt or CRM on HNSCC cells viability. FaDu and PE/CA-PJ49 cells were either left untreated or treated with different concentrations of CisPt or CRM for 6, 24 or 48 h. FaDu. Viability (\%) vs. untreated cells (100\%) was determined. Data shown are representative of three independent experiments and are expressed as mean of three replicates \pm SD $(n=3)$. Untreated cells were considered to have $100 \%$ viability. Viability $\%=(T-B) /(U-B) x 100,($ where $\mathrm{T}$, absorbance of treated cells; $\mathrm{U}$, absorbance of untreated cells; and B, absorbance of blank).

compared to the control (c; $\mathrm{P}=0.004$ ) (Fig. 3B). The data show that PE-CA/PJ49 cells having TP53 amplification are more sensitive to CRM treatment. CRM individually or in combination with CisPt can inhibit phosphorylation of protein ERK1/2 (Fig. 3B). FaDu having a TP53 deletion and constitutively a lower expression of phospho ERK1/2, does not respond to any of the treatments (Fig. 3B).

ERK1/2 activation correlates with the proliferation of tumor cells in HNSCC treated with cisplatin and/or curcumin. PE/CA-PJ49 and FaDu cells were treated with CisPt and/or CRM for 6, 24 and $48 \mathrm{~h}$. The cell proliferation index (PI) was not significantly changed during 6 h treatments. Moreover, PI for $48 \mathrm{~h}$ treatments was not significantly different compared to the $24 \mathrm{~h}$ of treatment. CRM treated cells also had a decreased PI ( $b ; \mathrm{P}=0.0004)$ for $\mathrm{FaDu}$ and for PE/CA-PJ49 (b; $\mathrm{P}=0.0006$ ) compared to the control (Fig. 4). CisPt treatment for $24 \mathrm{~h}$ determined a significant decrease of the proliferation process compared to the untreated cells, both in the case of tumoral cells FaDu (a; $\mathrm{P}=0.003)$ and in the cells PE/CA-PJ49 (a; $\mathrm{P}=0.0009)$. CRM treated cells also had a decreased PI (b; $\mathrm{P}=0.0004$ ) for FaDu and for PE/CA-PJ49 (b; P=0.0006) compared to the control. A marked PI inhibition was observed in both cell lines when the cells were treated simultaneously with CisPt and CRM (Fig. 4). The results are statistically significant when compared to the control (FaDu cells (c); $\mathrm{P}=0.0006$ and PE/CA-PJ49 (c) $\mathrm{P}=0.0005$ ) (Fig. 4). Based on the obtained data, CRM had the capacity to potentiate the effect induced by CisPt treatment on human head and neck cancer cell lines (Fig. 4).

Since the basal activation status of protein-kinase ERK1/2 in the analyzed tumor cell lines is different in the investigated cell lines, we studied the effect of ERK1/2 activation on the proliferation process as response to the drug treatment. Thus, the tumor cells were pretreated for $2 \mathrm{~h}$ with a specific ERK1/2 inhibitor, $25 \mu \mathrm{M}$ PD98059 (concentration determined after sketching the dose-effect curve) was used for pretreatments, and then the cells were treated with CisPt and/or CRM for another 24 h. FaDu cells have a TP53 deletion (Fig. 1) and a constitutively lower expression of phospho ERK1/2 (Fig. 3B). The presence of the specific inhibitor PD98059 did not influence significantly the proliferation process compared to control cells (no. PD98059) (P>0.05) (Fig. 4).

PE-CA/PJ49 cells have TP53 amplification (Fig. 1) and a constitutively high expression of phospho ERK1/2 (Fig. 3B). Pretreating with the PD98059 inhibitor of the PE-CA/PJ49 cells induced an increase of the proliferative activity in the case of treated cells with CisPt (d; $\mathrm{P}=0.005)$ or CRM (e; $\mathrm{P}=0.007)$. Similar effect was obtained in the case of the combined treatment of CRM and CisPt (f; $\mathrm{P}=0.003$ ), compared to the cells that were subject to the same treatment, but in the absence of the PD98059 inhibitor (Fig. 4). These results show that the inhibition of the ERK1/2 activity facilitates the restoration of the proliferative process of the CisPt and/or CRM treated PE-CA/PJ49 cells. These observations lead to the hypothesis that proliferation of tumor cells depends on the level of protein-kinase ERK1/2 activation.

The role of ERK1/2 in the activation of p53 in HNSCC cells treated with CisPt and/or CRM. FaDu and PE/CA-PJ49 were treated for $24 \mathrm{~h}$ as described, $10 \mu \mathrm{M}$ CisPt (a; P>0.05) did not affect the expression of total p53 protein in $\mathrm{FaDu}$ cells (Fig. 5A). On the contrary, $15 \mu \mathrm{M}$ CRM alone (b; $\mathrm{P}=0.003$ ) or combined with $\mathrm{CisPt}(\mathrm{c} ; \mathrm{P}=0.0001)$ induced a significant increase of total p53 expression compared to untreated cells (Fig. 5A). In the same cell line, the expression 
A

$\mathrm{FaDu}$

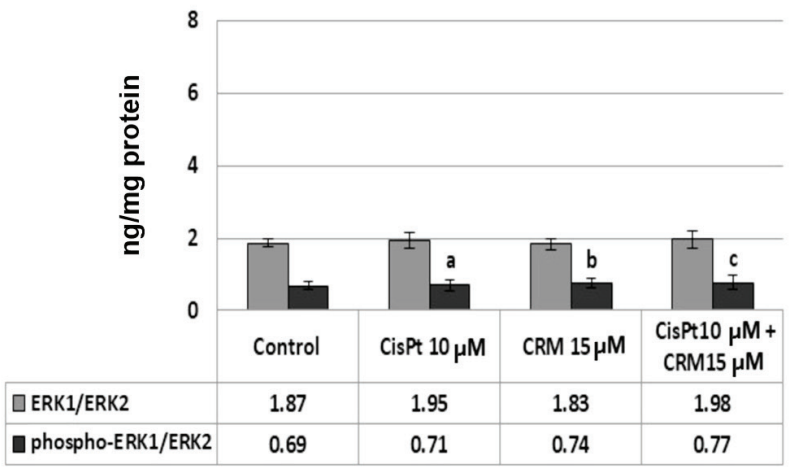

PE-CA/PJ49

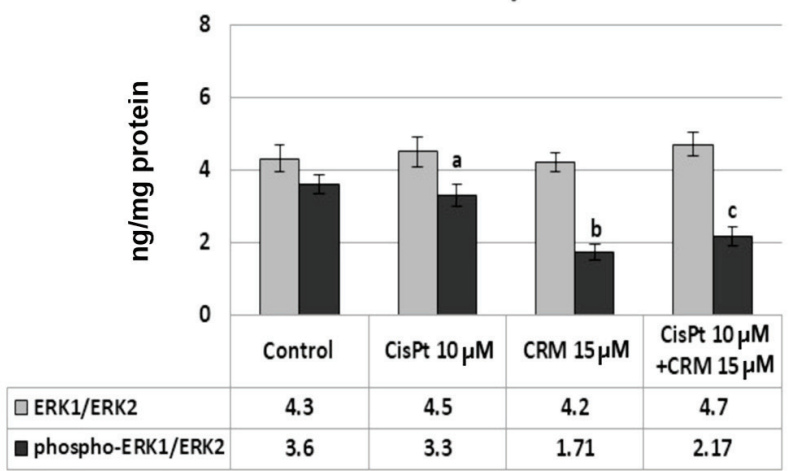

B

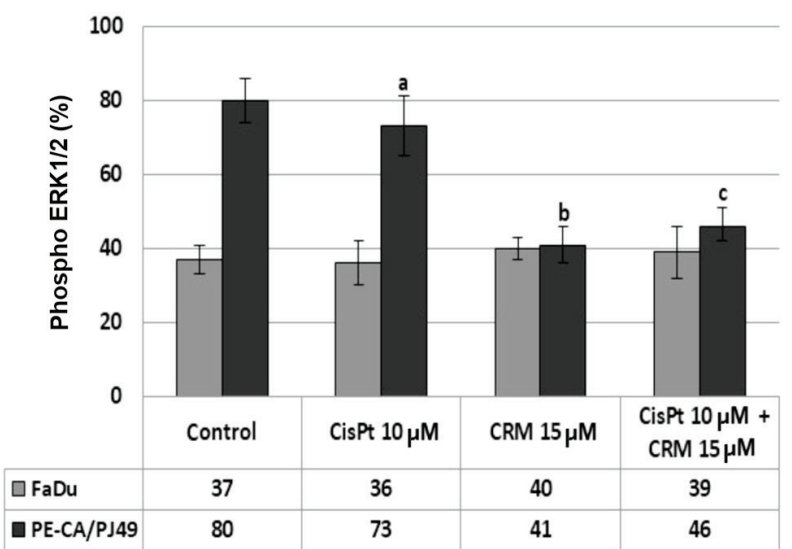

Figure 3. Effect of CisPt and/or CRM treatment on ERK1/2 protein-kinase expression in HNSCC tumor cell lines. (A) Total or phosphorylated ERK1/ERK2 protein concentrations in the cellular lysates are expressed as protein of interest/total protein $(\mathrm{ng} / \mathrm{mg}$ ). (B) The percent of phospho-ERK1/2 is calculated by formula: \% phospho-ERK1/2 = [(ng phospho ERK1/2/ng ERK1/2 total) x100]. The experiments were done in triplicates, data shown are representative of three independent experiments and were expressed as mean $\pm \mathrm{SD}$. a, CisPt vs. Control; b, CRM vs. Control; c, CisPt+CRM vs. Control; P>0.05, not significant.

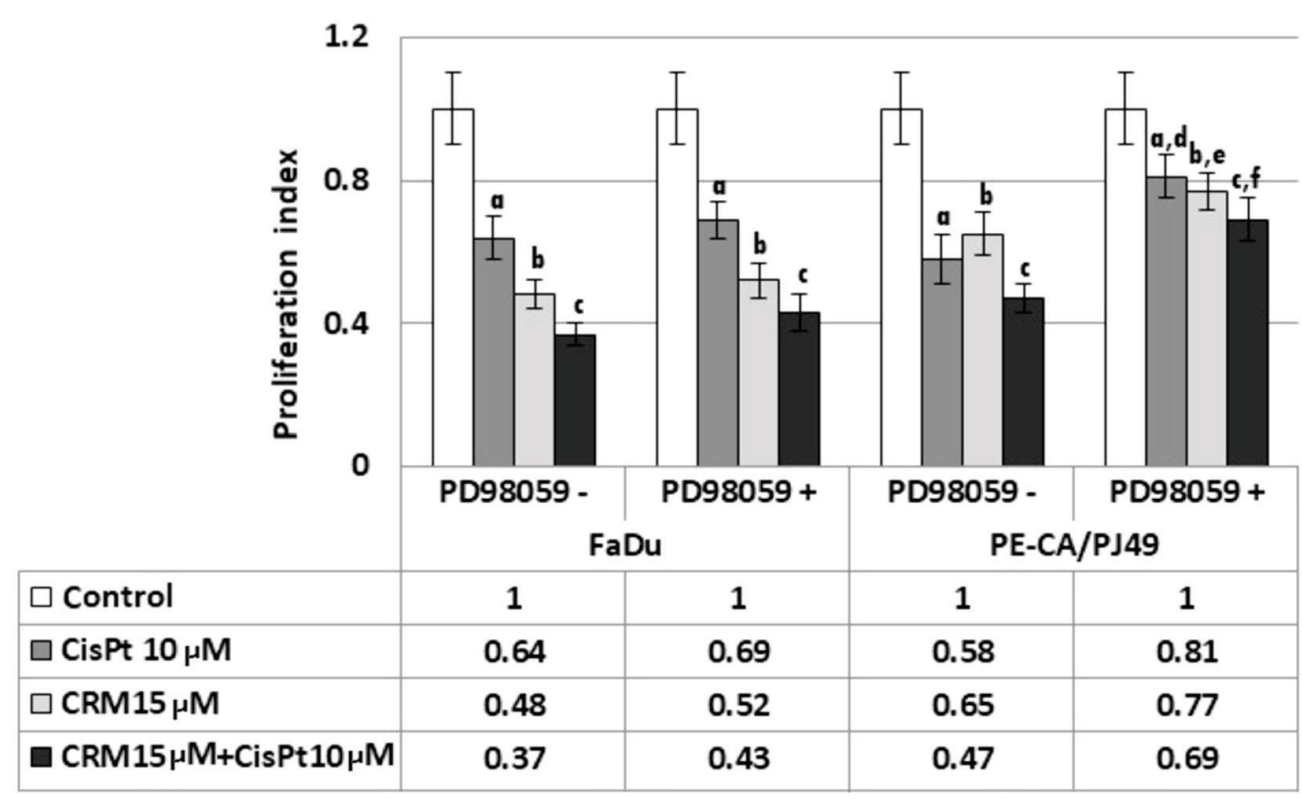

Figure 4. Downstream effect of phospho ERK1/2 inhibition. The proliferation index (PI) of FaDu and PE/CA-PJ49 cells treated with CisPt and/or CRM in the presence or absence of PD98059 was calculated. PI, absorbance of treated cells/absorbance of untreated cells. Results are expressed as mean values of three determinations \pm standard deviation (SD). Untreated cells were considered to have PI equal 1. a, CisPt vs. Control; b, CRM vs. Control; c, CisPt +CRM vs. Control; d, CisPt PD98059(-) vs. CisPt PD98059(+); e, CRM PD98059(-) vs. CRM PD98059(+) ; f, CisPt+CRM PD98059(-) vs. CisPt+CRM PD98059.

of phospho-p53 protein was inhibited by CisPt treatment compared to untreated cells (a; $\mathrm{P}=0.003$ ) (Fig. 5A). The expression of phospho-p53 showed a significant increase in the presence of either CRM alone $(b ; P=0.005)$ or 
A

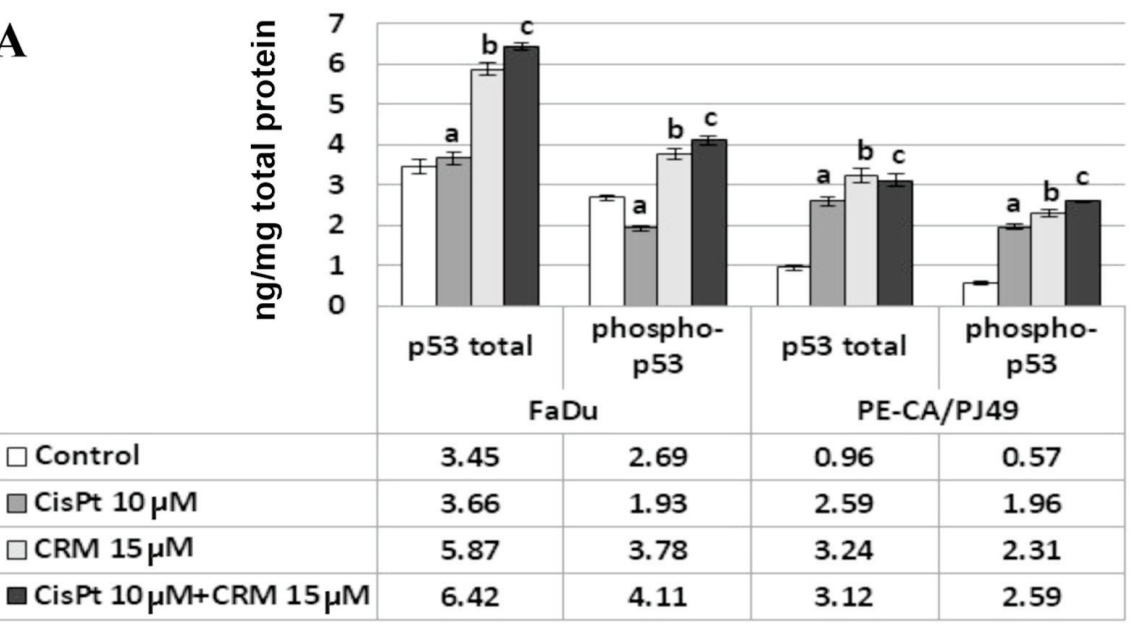

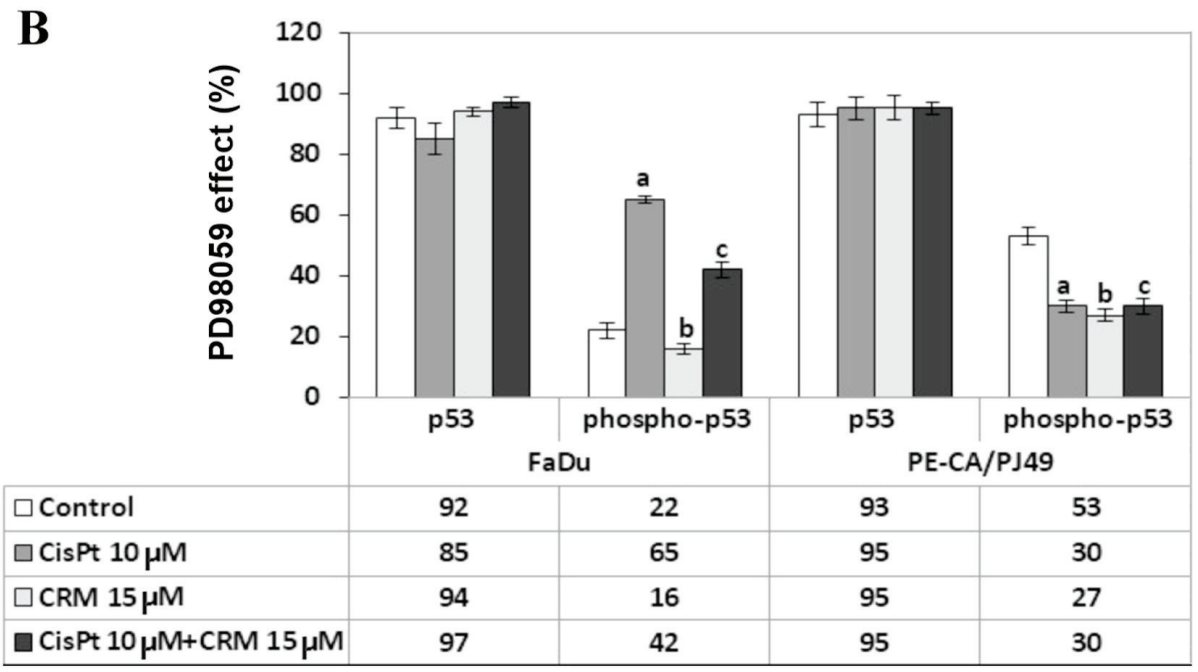

Figure 5. ERK1/2 in the activation of p53 in HNSCC cells treated with CisPt and/or CRM. (A) The total and phospho-p53 protein expression (ng/mg total protein lysate) in FaDu, PE/CA-PJ49 cells treated with CisPt and/or CRM. a, CisPt vs. Control; b, CRM vs. Control; c, CisPt+CRM vs. Control. (B) Inhibitory effect of PD98059 on the total and phospho-p53 expression. The experiments were performed in triplicates. Results are expressed as mean values of three determinations \pm standard deviation (SD). [PD98059 effect $(\%)=$ (protein expression+PD98059/protein expression-PD98059) x100]. a, CisPt vs. Control; b, CRM vs. Control; c, CisPt +CRM vs. Control.

combined with $\mathrm{CisPt}(\mathrm{c} ; \mathrm{P}=0.0007)$ compared to untreated cells (Fig. 5A).

The analysis of total p53 expression in PE/CA-PJ49 cells showed that either $\mathrm{CisPt}(\mathrm{a} ; \mathrm{P}=0.00006)$ or $\mathrm{CRM}$ treatment applied alone ( $b ; \mathrm{P}=0.002)$ induced a significant increase compared to control cells (Fig. 5A). The same result was obtained when cells were treated with the combined treatment $(\mathrm{c} ; \mathrm{P}=0.0001)$ (Fig. 5A). The p53 phosphorylation in $\mathrm{PE} / \mathrm{CA}-\mathrm{PJ} 49$ cells was amplified by either $\mathrm{CisPt}(\mathrm{a} ; \mathrm{P}=0.001)$ or CRM ( $b ; \mathrm{P}=0.0005)$ treatment compared to untreated cells. The combined treatment of CisPt and CRM amplified the expression of phospho-p53 (c; $\mathrm{P}=0.0002)$ compared to control, but the effect of the two agents was not additive (Fig. 5A).

In order to analyze the role of protein kinase ERK1/2 in the process of $\mathrm{p} 53$ phosphorylation, the HNSCC tumor cells were pretreated with $25 \mu \mathrm{M}$ PD98059 (specific inhibitor of ERK1/2) for $2 \mathrm{~h}$. Then, the cells were treated with CisPt and/or CRM for another $24 \mathrm{~h}$.
As Fig. 5B depicts the presence of PD98059 inhibitor did not significantly influence the level of total p53 expression (P>0.05). Untreated FaDu cells in the presence of PD98059 inhibitor expressed phospho-p53 in 22\%, while in the cells treated with CRM in $16 \%$ (b; $\mathrm{P}=0.03$ ). In the case of cells treated with CisPt alone the process of phosphorylation seems to be less affected by the presence of PD98059, the phosphorylated form of protein p53 being expressed in $65 \%$ (a; $\mathrm{P}=0.0007)$. The combined CisPt and CRM treatment in the presence of ERK1/2 inhibitor led to the decrease of the expression of phosphorylated p53 to $42 \%$ (c; $\mathrm{P}=0.0004$ ) (Fig. 5B).

In the PE/CA-PJ49 untreated cells, the presence of PD98059 reduced the phospho-p53 expression to 53\% (Fig. 5B). The presence of the specific ERK1/2 inhibitor significantly affected the level of $\mathrm{p} 53$ phosphorylation induced by either CisPt $(30 \%)(a ; \mathrm{P}=0.007)$ or CRM $(27 \%)(b ; \mathrm{P}=0.005)$ treatment. The combined CisPt and CRM treatment in the presence of PD98059 kept the phosphorylated form of protein p53 
A

FaDu

CTR

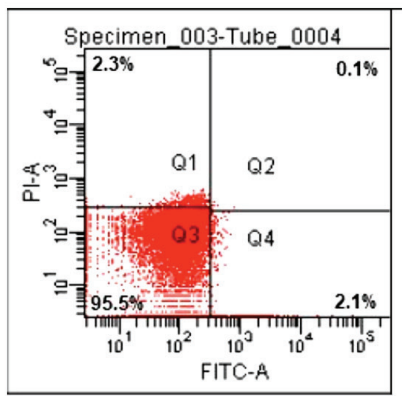

CRM $15 \mu M$
CisPt $10 \mu \mathrm{M}$

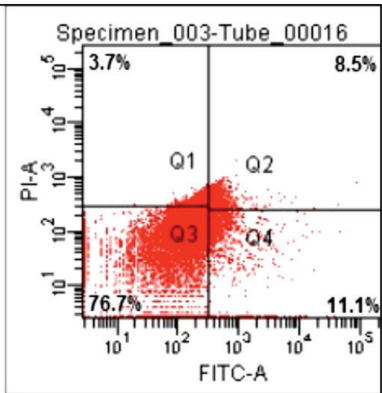

CisPt $10 \mu M+$

CRM $15 \mu \mathrm{M}$
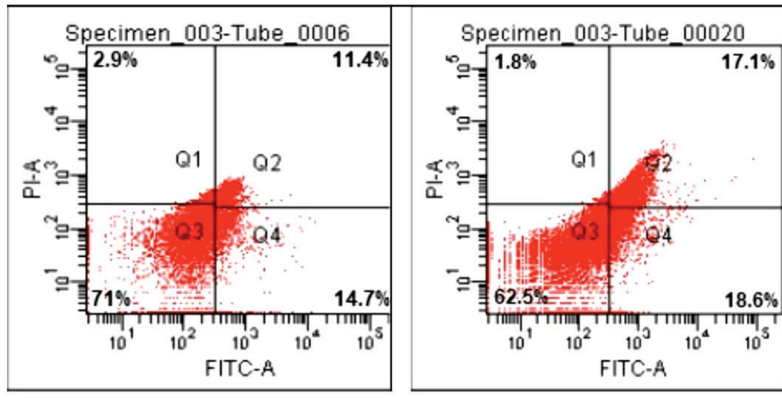

B

CTR

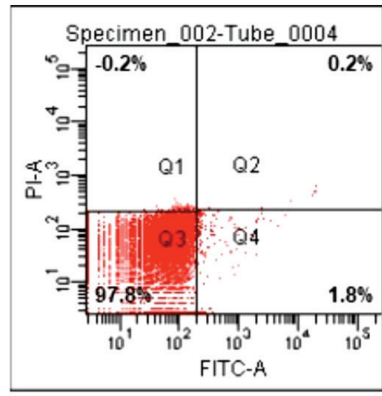

CRM $15 \mu M$
PE/CA-PJ49

\section{CisPt $10 \mu \mathrm{M}$}

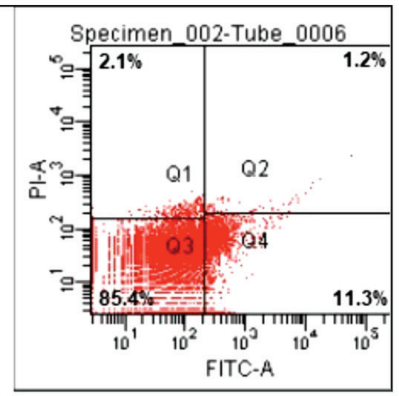

CisPt $10 \mu \mathrm{M}+$

\section{CRM 15 $\mu$ M}
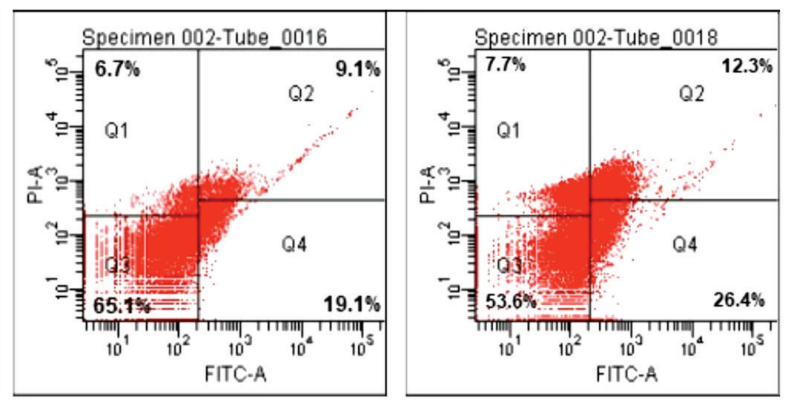

\section{C}

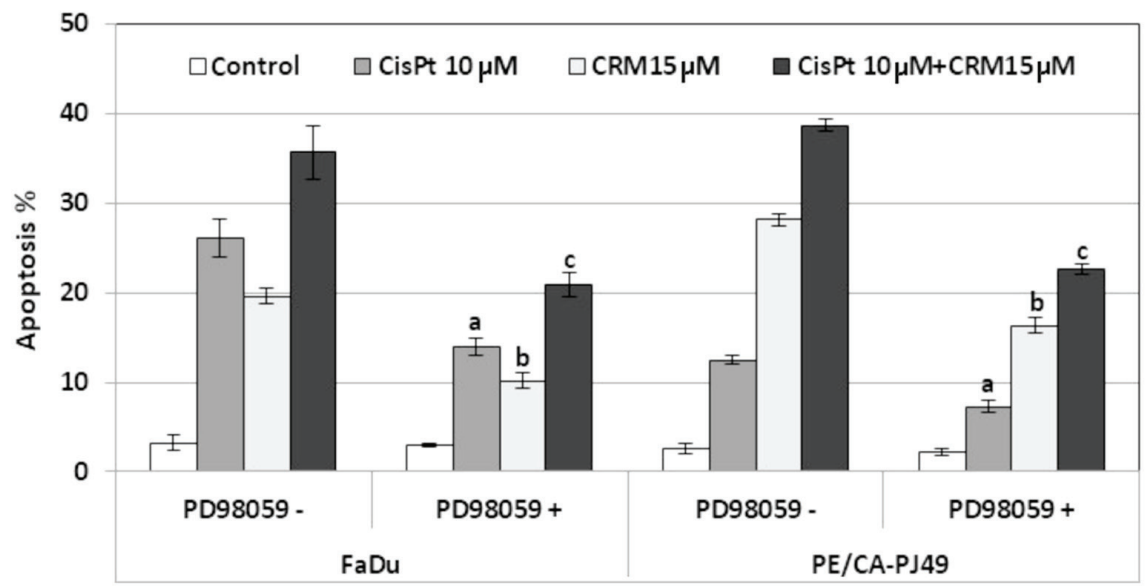

Figura 6. Apoptosis of HNSCC cells treated with CisPt and/or CRM. Apoptosis of FaDu (A) and PE/CA-PJ49 (B) cells treated with CisPt and/or CRM in the presence or absence of the PD98059 inhibitor (C). a, CisPt PD98059(-) vs. CisPt PD98059(+); b, CRM PD98059(-) vs. CRM PD98059(+); c, CisPt+CRM PD98059(-) vs. CisPt+CRM PD98059(+).

to $30 \%$ (c; $\mathrm{P}=0.007)$ since the effect of the two agents was not additive (Fig. 5B).

ERK1/2 in the modulation of HNSCC apoptosis induced by CisPt and/or CRM treatment. FaDu and PE/CA-PJ49 were treated for $24 \mathrm{~h}$ with $10 \mu \mathrm{M}$ CisPt, $15 \mu \mathrm{M}$ CRM, combined treatment and compared to control cells (untreated). CisPt treated FaDu cells had 9 times enhancement of the apoptotic events $(19.6 \%)$ compared to untreated cells (2.2\%). CRM treated FaDu cells had a 12 times higher apoptosis $(26.1 \%)$ than untreated cells. The combined treatment of CisPt and
CRM induced $35.7 \%$ apoptosis. This indicates a 16 times higher apoptosis than in the untreated cells. Moreover, apoptosis was almost twice higher $(1.8 \mathrm{x})$ than the value obtained for CisPt treatment alone. This indicates that CRM amplified the apoptotic process and supported the tumoricidal effect of CisPt (Fig. 6A).

CisPt treatment of PE/CA-PJ49 cells induced a 6x higher apoptosis (12.5\%) compared to untreated cells $(2.0 \%)$. In the same manner, apoptosis induced by CRM alone $(28.8 \%)$ or combined treatment of CisPt and CRM (38.7\%) was 14x and respectively 19x higher compared to untreated cells. CRM 
significantly amplified the effect induced by CisPt treatment on the PE/CA-PJ49 apoptotic process since apoptosis was 3x higher than the value obtained for CisPt treatment (Fig. 6B).

Our data support the CRM apoptosis inducer capabilities considering that CRM had the capacity to induce apoptosis in both tumor lines. Also, CRM potentiated the effect induced by CisPt treatment.

In order to analyze the role of ERK1/2 protein kinase in the modulation of the apoptotic process, HNSCC tumor cells were pretreated for $2 \mathrm{~h}$ with $25 \mu \mathrm{M}$ ERK1/2 specific inhibitor, PD98059. Then the cells were treated for $24 \mathrm{~h}$ with $\mathrm{CisPt}$ and/or CRM, and subjected to flow cytometric analysis of the apoptotic process. As shown in Fig. 6C, the PD98059 inhibition of ERK1/2 protein kinase led to a decrease of the apoptotic cell percentage in both cell lines compared to untreated cells. The decreased was statistically significant for all treatments as follows: FaDu cells (a) CisPt treated $\mathrm{P}=0.007$; (b) $\mathrm{CRM}$ treated $\mathrm{P}=4.4 \mathrm{E}-05$; (c) combined treatment; $\mathrm{P}=0.004$; PE/CA-PJ49 cells (a) CisPt treated $\mathrm{P}=0.006$; (b) $\mathrm{CRM}$ treated $\mathrm{P}=5.1 \mathrm{E}-05$; (c) combined treatment $\mathrm{P}=0.0003$. These results demonstrate the involvement of ERK1/2 protein kinase in the apoptotic mechanisms induced by $\mathrm{CisPt}$ and/or CRM on the analyzed tumor cells.

\section{Discussion}

The essential step during carcinogenesis of oral squamous cell carcinomas is the acquisition of genetic instability that occurs at the nucleotide or the chromosome level (48). The genotypic abnormalities such as polysomy of chromosome 17 may be associated with the development of an early recurrence or second primary tumors and can influence the therapy response (49). In this study the effect of CisPt and/or CRM treatment on two HNSCC tumor cell lines (FaDu and PE/CA-PJ49) were analyzed. One of the most frequent genetic abnormalities associated with HNSCC affects p53 onco-supressor gene. Abnormalities in the p53 gene cause an inefficient checkpoint system for the repair and destruction of mutant cells. The cell lines were analyzed using FISH analysis to detect the possible alterations of chromosome 17 involving the TP53 gene. PE/CA-PJ49 cell line had an amplification of the TP53 gene associated with polysomy in chromosome 17. FaDu tumor line presented a deletion in gene TP53, without chromosome 17 modifications. This data can explain the different response of each cell line to CisPt and/or CRM treatment.

Genetic modifications, as well as p53 protein expression alterations could influence the activation of several intracellular signaling pathways, such as ERK1/2 and therefore it could contribute to the modulation of the response to therapy. In many studies, the ERK signaling pathway is associated with proliferative (50) and cellular differentiation processes (51) on one hand, and on the other hand, there are studies showing that this pathway has a role in the apoptotic process (52-54). This suggests its importance in the modulation of the response to antitumor therapy (55). The activation status of ERK1/2 in HNSCC cell lines was evaluated to establish if the cellular response to CisPt and/or CRM treatment is influenced by the level of ERK1/2 activation. Expression of the total and phosphorylated ERK1/2 protein was quantified in treated and untreated cells. The data show that the total and phosphorylated ERK1/2 protein expression is much higher in untreated PE/CA-PJ49 than in FaDu cells. FaDu cell line treated with CisPt and/or CRM did not show a significant change of ERK1/2 phosphorylation. A significant decrease of phospho ERK1/2 was observed in PE/CA-PJ49 cells treated with CisPt and CRM. The constitutively expressed activated ERK1/2 protein-kinase was different in the two tumor cell lines. This was reflected in downstream events such as the cell proliferation process. The inhibition of ERK1/2 activity using PD98059 did not significantly affect the proliferation of the cells (e.g. FaDu) having a low expression of the protein. Cells with a constitutively high expression of ERK1/2 protein-kinase (PE/CA-PJ49) responded to the presence of the inhibitor by reversing the proliferative process. This suggests the existence of an ERK1/2 protein-kinase activation threshold which modulates the proliferative process of tumor cells.

How p53 responds to the drug treatment of tumor cells having a different expression pattern of ERK1/2 was evaluated. In untreated cells, the expression of total and phosphorylated p53 was higher in FaDu compared to PE/CA-PJ49 cells (Fig. 5A). This difference can be associated with the amplification of p53 gene in PE/CA-PJ49 cells and the p53 deletion in tumor cells FaDu (Fig. 1). CRM treatment induced an increase of the total p53 protein expression associated with an increase of the phosphorylation process in both cell lines. The response of $\mathrm{FaDu}$ cells to CisPt treatment led to a decrease of the phosphorylation process without affecting the expression of total p53 protein, while CisP induced a significant increase of p53 phosphorylation in PE/CA-PJ49 tumor cells (Fig. 5A and B).

The response of FaDu CRM treated cells in the presence of ERK1/2 inhibitor PD98059 suggest that the ERK1/2 might be involved in the $\mathrm{p} 53$ phosphorylation. The response of $\mathrm{FaDu}$ CisPt treated cells to the presence of the same inhibitor suggests that p53 upstream events might follow a different pathway than ERK1/2. Regardless of the treatment of PE/CA-PJ49 cells, phosphorylation of p53 involved ERK1/2 activation. Moreover, the results support the involvement of ERK1/2 and phospho p53 in CisPt and/or CRM induced apoptosis. Many studies support the antitumor and pro-apoptotic effect of CRM (56-58). It is not well known if the effect of CRM is due to the existence of a link between the activation level of ERK1/2 and the apoptotic process. The results of our study show that CRM increased the apoptotic process in both tumor cell lines. CRM acts as an apoptosis-inducer factor and more importantly potentiates the effect induced by CisPt treatment (Fig. 6).

Conclusions and future directions. The results showed that the tumor cell line FaDu presented a deletion of the TP53 gene, while cell line PE-CA/PJ49 presented polysomy. Both modifications are associated with cell proliferation and response to therapy. The use of an adjuvant (CRM) can increase the efficiency of chemotherapy (CisPt) effect by modulating cell activation processes such as ERK1/2 phosphorylation. The presence of the adjuvant can decrease the required dose of drug, therefore reducing the chemotherapeutic adverse reactions of the agent.

The data show that the ERK1/2 way of action either on cell proliferation or apoptosis depends on the type of cell 
characteristics and therapeutic agents. In order to achieve an efficient personalized therapy, more investigations are necessary for a better functional interpretation of the intracellular signaling pathways.

In conclusion, evaluating the level of ERK1/2 activation in tumor cells can be a useful tool for an individualized treatment plan, but in order to achieve this goal extended investigations on patient tumor specimens are needed.

\section{Acknowledgements}

Not applicable.

\section{Funding}

This study was supported by Grants PN-III-P1-1.2-P CCDI-2017-0341/2018,PN-III-P1-1.2-PCCDI-2017-0782/2018, PN 19.29.01.01, and by Ministry of Research and Innovation in Romania, under Program 1 - The Improvement of the National System of Research and Development, Subprogram 1.2 Institutional Excellence - Projects of Excellence Funding in RDI, contract no. 7PFE/16.10.2018.

\section{Availability of data and materials}

The data sets used and/or analysed during the present study are available from the corresponding author on reasonable request.

\section{Authors' contributions}

MB and MTN, designed the research, data acquisition, analysis and interpretation of data, and wrote the manuscript. MB, MM and GGPM performed the experiments, data acquisition, analysis and interpretation of data, statistical analysis and manuscript drafting. VR, GI, LIB, RH, NR and CC contributed to data collection and interpretation, statistical analysis, critical revision of the manuscript for important intellectual content. All the authors read and approved the final manuscript, and had equal contribution.

\section{Ethics approval and consent to participate}

The study protocol was approved by the Ethics Committee of 'Stefan S. Nicolau' Virology Institute.

\section{Patient consent for publication}

Not applicable.

\section{Competing interests}

The authors declare that they have no competing interests.

\section{References}

1. Ursu RG, Danciu M, Spiridon IA, Ridder R, Rehm S, Maffini F, McKay-Chopin S, Carreira C, Lucas E, Costan VV, et al: Role of mucosal high-risk human papillomavirus types in head and neck cancers in Romania. PLoS One 13: e0199663, 2018.
2. Forman D, Bray F, Brewster DH, Gombe Mbalawa C, Kohler B, Piñeros M, Steliarova-Foucher E, Swaminathan R and Ferlay J (eds): Cancer Incidence in Five Continents Vol. X. International Agency for Research on Cancer, Lyon, 2014.

3. Ferlay J, Shin HR, Bray F, Forman D, Mathers C and Parkin DM: Estimates of worldwide burden of cancer in 2008: GLOBOCAN 2008. Int J Cancer 127: 2893-2917, 2010.

4. Kumar M, Nanavati R, Modi TG and Dobariya C: Oral cancer: Etiology and risk factors: A review. J Cancer Res Ther 12: 458-463, 2016.

5. Vigneswaran $\mathrm{N}$ and Williams MD: Epidemiologic trends in head and neck cancer and aids in diagnosis. Oral Maxillofac Surg Clin North Am 26: 123-141, 2014.

6. Vermorken JB, Remenar E, van Herpen C, Gorlia T, Mesia R, Degardin M, Stewart JS, Jelic S, Betka J, Preiss JH, et al; EORTC 24971/TAX 323 Study Group: Cisplatin, fluorouracil, and docetaxel in unresectable head and neck cancer. N Engl J Med 357: 1695-1704, 2007.

7. Jimenez L, Jayakar SK, Ow TJ and Segall JE: Mechanisms of invasion in head and neck cancer. Arch Pathol Lab Med 139: 1334-1348, 2015.

8. Voiculescu VM, Caruntu C, Solomon I, Lupu M, Ilie MA, Boda D, Constantin C and Neagu M: Squamous cell carcinoma: Biomarkers and potential therapeutic targets. In: Human Skin Cancers - Pathways, Mechanisms, Targets and Treatments. Blumenberg M (ed). IntechOpen, London, pp135-159, 2018.

9. Torre LA, Bray F, Siegel RL, Ferlay J, Lortet-Tieulent J and Jemal A: Global cancer statistics, 2012. CA Cancer J Clin 65: 87-108, 2015.

10. Zhai TT, van Dijk LV,Huang BT,LinZX, Ribeiro CO, BrouwerCL, Oosting SF, Halmos GB, Witjes MJH, Langendijk JA, et al: Improving the prediction of overall survival for head and neck cancer patients using image biomarkers in combination with clinical parameters. Radiother Oncol 124: 256-262, 2017.

11. Lupu M, Caruntu A, Caruntu C, Boda D, Moraru L, Voiculescu V and Bastian A: Non-invasive imaging of actinic cheilitis and squamous cell carcinoma of the lip. Mol Clin Oncol 8: 640-646, 2018.

12. Boda D, Docea AO, Calina D, Ilie MA, Caruntu C, Zurac S, Neagu M, Constantin C, Branisteanu DE, Voiculescu V, et al: Human papilloma virus: Apprehending the link with carcinogenesis and unveiling new research avenues (Review). Int J Oncol 52: 637-655, 2018.

13. Hassan M, Watari H, AbuAlmaaty A, Ohba Y and Sakuragi N: Apoptosis and molecular targeting therapy in cancer. BioMed Res Int 2014: 150845, 2014.

14. Neagu M, Constantin C, Popescu ID, Zipeto D, Tzanakakis G, Nikitovic D, Fenga C, Stratakis CA, Spandidos DA and Tsatsakis AM: Inflammation and metabolism in cancer cell - mitochondria key player. Front Oncol 9: 348, 2019.

15. Cagnol S and Chambard JC: ERK and cell death: Mechanisms of ERK-induced cell death - apoptosis, autophagy and senescence. FEBS J 277: 2-21, 2010.

16. Huang J, Zhang J, Shi C, Liu L and Wei Y: Survival, recurrence and toxicity of HNSCC in comparison of a radiotherapy combination with cisplatin versus cetuximab: A meta-analysis. BMC Cancer 16: 689, 2016.

17. Neagu M, Caruntu C, Constantin C, Boda D, Zurac S, Spandidos DA and Tsatsakis AM: Chemically induced skin carcinogenesis: Updates in experimental models (Review). Oncol Rep 35: 2516-2528, 2016.

18. Kass JI, Moskowitz HS and Grandis JR: Oncogenomics/ Proteomics of Head and Neck Cancers. Head and Neck Cancer. In: Multimodality Management. 2nd edition. Springer International Publishing, New York, NY, pp101-114, 2016.

19. Chen L and Tweddle DA: p53, SKP2, DKK3 as MYCN target genes and their potential therapeutic significance. Cancer Molecular Targets and Therapeutic. Front Oncol 2: 173, 2012

20. Boda D: Cellomics as integrative omics for cancer. Curr Proteomics 10: 237-245, 2013.

21. Powell E, Piwnica-Worms D and Piwnica-Worms H: Contribution of p53 to metastasis. Cancer Discov 4: 405-414, 2014.

22. Samatar AA and Poulikakos PI: Targeting RAS-ERK signalling in cancer: Promises and challenges. Nat Rev Drug Discov 13: 928-942, 2014.

23. Solomon I, Voiculescu VM, Caruntu C, Lupu M, Popa A, Ilie MA, Albulescu R, Caruntu A, Tanase C, Constantin C, et al: Neuroendocrine factors and head and neck squamous cell carcinoma: An affair to remember. Dis Markers 2018: 9787831, 2018. 
24. Yang SH, Sharrocks AD and Whitmarsh AJ: MAP kinase signalling cascades and transcriptional regulation. Gene 513: $1-13,2013$

25. Lupu M, Caruntu A, Caruntu C, Papagheorghe LM, Ilie MA Voiculescu V, Boda D, Constantin C, Tanase C, Sifaki M, et al: Neuroendocrine factors: The missing link in non melanoma skin cancer (Review). Oncol Rep 38: 1327-1340, 2017.

26. Burotto M, Chiou VL, Lee JM and Kohn EC: The MAPK pathway across different malignancies: A new perspective. Cancer 120: 3446-3456, 2014.

27. Urosevic J, Nebreda AR and Gomis RR: MAPK signaling control of colon cancer metastasis. Cell Cycle 13: 2641-2642, 2014

28. Tanase CP, Neagu M and Albulescu R: Key signaling molecules in pituitary tumors. Expert Rev Mol Diagn 9: 859-877, 2009.

29. Yang M and Huang CZ: Mitogen-activated protein kinase signaling pathway and invasion and metastasis of gastric cancer. World J Gastroenterol 21: 11673-11679, 2015.

30. Peng Q, Deng Z, Pan H, Gu L, Liu O and Tang Z: Mitogen-activated protein kinase signaling pathway in oral cancer. Oncol Lett 15: 1379-1388, 2018.

31. Kumari R, Chouhan S, Singh S, Chhipa RR, Ajay AK and Bhat MK: Constitutively activated ERK sensitizes cancer cells to doxorubicin: Involvement of p53-EGFR-ERK pathway. J Biosci 42: 31-41, 2017.

32. Wang J, Luo L, Wang D, Guo B, Li J, Yang Z and Tang D: Combination adjuvant chemotherapy with targeted drugs for treatment of colorectal cancer: A network meta-analysis. J Cel Biochem 119: 1521-1537, 2018

33. Bailon-Moscoso N, Cevallos-Solorzano G, Romero-Benavides JC and Orellana MI: Natural compounds as modulators of cell cycle arrest: Application for anticancer chemotherapies. Curr Genomics 18: 106-131, 2017.

34. Seca AM and Pinto DC: Plant secondary metabolites as anticancer agents: Successes in clinical trials and therapeutic application. Int J Mol Sci 19: E263, 2018.

35. Shanmugam MK, Rane G, Kanchi MM, Arfuso F, Chinnathambi A, Zayed ME, Alharbi SA, Tan BK, Kumar AP and Sethi G: The multifaceted role of curcumin in cancer prevention and treatment. Molecules 20: 2728-2769, 2015

36. Miao Y, Zhao S, Gao Y, Wang R, Wu Q, Wu H and Luo T: Curcumin pretreatment attenuates inflammation and mitochondrial dysfunction in experimental stroke: The possible role of Sirt1 signaling. Brain Res Bull 121: 9-15, 2016.

37. Shi D, Xu Y, Du X, Chen X, Zhang X, Lou J, Li M and Zhuo J: Co-treatment of THP-1 cells with naringenin and curcumin induces cell cycle arrest and apoptosis via numerous pathways. Mol Med Rep 12: 8223-8228, 2015.

38. Patel PB, Thakkar VR and Patel JS: Cellular effect of curcumin and citral combination on breast cancer cells: Induction of apoptosis and cell cycle arrest. J Breast Cancer 18: 225-234, 2015

39. Neagu M, Constantin C, Tanase C and Boda D: Patented biomarker panels in early detection of cancer. Recent Pat Biomark 1: 10-24, 2011.

40. Chen XY, Cai HZ, Wang XY, Chen QY, Yang H, Chen YJ, Tang YP: Application of the ERK signaling pathway inhibitor PD98059 in long-term in vivo experiments. Genet Mol Res 14: 18325-33, 2015.

41. Barltrop JA, Owen TC, Cory AH and Cory JG: 5-(3-carboxymetho xyphenyl)-2-(4,5-dimenthylthiazoly)-3-(4-sulfophenyl)tetrazolium, inner salt (MTS) and related analogs of 3-(4,5-dimethylthiazolyl)2,5-diphenyltetrazolium bromide (MTT) reducing to purple water-soluble formazans as cell-viability indicators. Bioorg Med Chem Lett 1: 611-614, 1991.

42. Petrică-Matei GG, Iordache F, Hainăroşie R and Bostan M: Characterization of the tumor cells from human head and neck cancer. Rom J Morphol Embryol 57 (Suppl 2): 791-799, 2016.

43. Hirshberg A, Yarom N, Amariglio N, Yahalom R, Adam I Stanchescu R, Ben-Dov I, Taicher S, Rechavi G and Trakhtenbrot L: Detection of non-diploid cells in premalignant and malignant oral lesions using combined morphological and FISH analysis - a new method for early detection of suspicious oral lesions. Cancer Lett 253: 282-290, 2007.
44. Salido M, Tusquets I, Corominas JM, Suarez M, Espinet B, Corzo C, Bellet M, Fabregat X, Serrano S and Solé F: Genetic alterations of chromosome 17 in human breast carcinoma studied by fluorescence in situ hybridization and molecular DNA techniques. Breast Cancer Res 7: 267-273, 2005.

45. Sunahori K, Nagpal K, Hedrich CM, Mizui M, Fitzgerald LM and Tsokos GC: The catalytic subunit of protein phosphatase $2 \mathrm{~A}$ (PP2Ac) promotes DNA hypomethylation by suppressing the phosphorylated mitogen-activated protein kinase/extracellular signal-regulated kinase (ERK) kinase (MEK)/phosphorylated ERK/DNMT1 protein pathway in T-cells from controls and systemic lupus erythematosus patients. J Biol Chem 288: 21936-21944, 2013.

46. Bundscherer A, Malsy M, Lange R, Hofmann P, Metterlein T, Graf BM and Gruber M: Cell harvesting method influences results of apoptosis analysis by Annexin V staining. Anticancer Res 33: 3201-3204, 2013.

47. Zedan W, Mourad MI, El-Aziz SMA, Salamaa NM and Shalaby AA: Cytogenetic significance of chromosome 17 aberrations and P53 gene mutations as prognostic markers in oral squamous cell carcinoma. Diagn Pathol 10: 2, 2015.

48. Jin C, Jin Y, Wennerberg J, Akervall J, Dictor M and Mertens F: Karyotypic heterogeneity and clonal evolution in squamous cell carcinomas of the head and neck. Cancer Genet Cytogenet 132: 85-96, 2002.

49. Papavasileiou D, Tosios K, Christopoulos P, Goutas N and Vlachodimitropoulos D: Her-2 immunohistochemical expression in oral squamous cell carcinomas is associated with polysomy of chromosome 17, not Her-2 amplification. Head Neck Pathol 3: 263-270, 2009.

50. Wang L, Liu T, Nishioka M, Aguirre RL, Win SS and Okada N: Activation of ERK1/2 and cyclin D1 expression in oral tongue squamous cell carcinomas: Relationship between clinicopathological appearances and cell proliferation. Oral Oncol 42: 625-631, 2006.

51. Chambard JC, Lefloch R, Pouysségur J and Lenormand P: ERK implication in cell cycle regulation. Biochim Biophys Acta 1773: 1299-1310, 2007.

52. Aguzzi A, Maggioni D, Nicolini G, Tredici G, Gaini RM and Garavello W: MAP kinase modulation in squamous cell carcinoma of the oral cavity. Anticancer Res 29: 303-308, 2009.

53. Kim EK and Choi EJ: Pathological roles of MAPK signaling pathways in human diseases. Biochim Biophys Acta 1802: 396-405, 2010

54. Engelbrecht AM, Gebhardt S and Louw L: Ex vivo study of MAPK profiles correlated with parameters of apoptosis during cervical carcinogenesis. Cancer Lett 235: 93-99, 2006.

55. Squatrito M, Brennan CW, Helmy K, Huse JT, Petrini JH and Holland EC: Loss of ATM/Chk2/p53 pathway components accelerates tumor development and contributes to radiation resistance in gliomas. Cancer Cell 18: 619-629, 2010.

56. Hasima N and Aggarwal BB: Cancer-linked targets modulated by curcumin. Int J Biochem Mol Biol 3: 328-351, 2012.

57. Baharuddin P, Satar N, Fakiruddin KS, Zakaria N, Lim MN, Yusoff NM, Zakaria Z and Yahaya BH: Curcumin improves the efficacy of cisplatin by targeting cancer stem-like cells through p21 and cyclin D1-mediated tumour cell inhibition in non-small cell lung cancer cell lines. Oncol Rep 35: 13-25, 2016.

58. Borges GÁ, Rêgo DF, Assad DX, Coletta RD, De Luca Canto G and Guerra EN: In vivo and in vitro effects of curcumin on head and neck carcinoma: A systematic review. J Oral Pathol Med 46: 3-20, 2017.

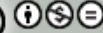

This work is licensed under a Creative Commons Attribution-NonCommercial-NoDerivatives 4.0 International (CC BY-NC-ND 4.0) License. 